\title{
Meta
}

Journal des traducteurs

Translators' Journal

\section{Translation in Historiography: The Garibay/León-Portilla Complex and the Making of a Pre-Hispanic Past}

\section{Gertrudis Payàs}

Volume 49, numéro 3, septembre 2004

L'histoire de la traduction et la traduction de l'histoire

History of Translation and Translation of History

URI : https://id.erudit.org/iderudit/009378ar

DOI : https://doi.org/10.7202/009378ar

Aller au sommaire du numéro

Éditeur(s)

Les Presses de l'Université de Montréal

ISSN

0026-0452 (imprimé)

1492-1421 (numérique)

Découvrir la revue

Citer cet article

Payàs, G. (2004). Translation in Historiography: The Garibay/León-Portilla Complex and the Making of a Pre-Hispanic Past. Meta, 49(3), 544-561.

https://doi.org/10.7202/009378ar
Résumé de l'article

Historiens et anthropologues doivent à l'occasion traduire ou utiliser des traductions pour avoir accès aux sources écrites dans d'autres langues. L'historiographie mexicaine illustre bien la chose. En fait, une partie non négligeable de ce que nous savons sur la période préhispanique nous a été révélée par des traductions. Dans ce travail, j'analyse la façon dont les deux principaux mésoaméricanistes mexicains abordent la traduction. 


\title{
Translation in Historiography: The Garibay/León-Portilla Complex and the Making of a Pre-Hispanic Past*
}

\author{
GERTRUDIS PAYÀS \\ University of Ottawa, Ottawa, Canada \\ payas@lagerta.com
}

\begin{abstract}
RÉSUMÉ
Historiens et anthropologues doivent à l'occasion traduire ou utiliser des traductions pour avoir accès aux sources écrites dans d'autres langues. L'historiographie mexicaine illustre bien la chose. En fait, une partie non négligeable de ce que nous savons sur la période préhispanique nous a été révélée par des traductions. Dans ce travail, j'analyse la façon dont les deux principaux mésoaméricanistes mexicains abordent la traduction.
\end{abstract}

\begin{abstract} have approached translation will be the focus of this work.

\section{MOTS-CLÉS/KEYWORDS}

mesoamericanism, historiography, nahuatl, Garibay, León-Portilla
\end{abstract}

Historians and anthropologists sometimes need to translate or to use translations in order to have access to sources written in other languages. Mexican historiography is one such case. Indeed, a good part of what we know about pre-Hispanic times has been revealed through translations. How the two most prominent Mexican Mesoamericanists

Historians and anthropologists sometimes need to translate or to use translations in order to have access to sources written in other languages. Translation in their hands differs from translation performed by "professional translators" in one important aspect: at least theoretically, the objective of translation performed by the professional translator is the transfer itself. Somebody else will use our translations for his or her purposes. But when the historian ${ }^{* *}$ translates, he is both translator and enduser. Indeed, he is even more than that: he "orders" the translation by choosing the text from a selection of other sources; sometimes he also carries out the paleography and the edition, then he translates and uses the translation to support his findings. Translation is thus a significant part of the historiographical process, involving a number of decisions. The purpose of translation in the hands of the historian is history-making, apparently through the obtention of evidence that is considered dormant in untapped written sources. Translations in the hands of historians, therefore, are important because they are expected to deliver some otherwise unavailable understanding of the past. Exploring the way in which Mexican Middle-Americanists (or Mesoamericanists) Angel María Garibay and Miguel León-Portilla view the relationship between the pre-Columbian past and its traces, as well as the way in which they have extracted meaning from these traces through translation, the representations conveyed by these translations and the implications therefrom will constitute the focus of this paper. 
For a long time, the traces of the pre-Columbian past were, firstly, the monuments (the ruins of pyramids and so forth), then the sculpture, ceramics and paintings, and lastly the few codexes kept in some foreign museums and libraries: a civilization represented chiefly by material remains and lacking a written tradition, thus considered "primitive," pre-historical.

When, during the 1930's and 40’s, Mexican Catholic priest Ángel María Garibay started the study and translation of texts written in alphabetical Nahuatl under the supervision of the first Spanish missionaries, notably the 16th century corpus entitled Cantares Mexicanos to which we will refer here, he was creating a literature for this great civilization. Until then the pyramid had been a "silent witness of the past"; from then on, the pyramid would have a voice.

\section{Garibay and the birth of a literature through translation}

Father Ángel María Garibay was born in 1892 and died in 1967. He lived through the Mexican Revolution, the turbulent post-Revolutionary period and the religious persecutions of the Cristera War. His is also the time of great definitions, the time of building of modern nationalism, formulated by archaeologist Manuel Gamio, and nourished by another archaeologist, Alfonso Caso, with the widely publicized diggings in Teotihuacán (State of Mexico), Templo Mayor (Mexico City) and Monte Albán (State of Oaxaca). During these years, national institutions were created to protect the newly discovered monuments (Dirección de Antropología in 1917; Departamento de Monumentos Prehispánicos in 1925, and the Instituto Nacional de Antropología e Historia in 1939, with its attached Escuela Nacional de Antropología e Historia). It is not of little relevance that Garibay received in 1965, from the then President, Gustavo Díaz Ordaz, the Premio Literario de Historia y Letras together with the architect of the Museo Nacional de Antropología, Pedro Ramírez Vázquez, since both works are emblematic of the Aztec archetype. As a parallel development, the State's "indigenist" policy was created, by which the marginalized ethnic groups would be incorporated within the modern nation (although on this point Garibay believed that the solution ot the indigenous people's plight was a matter of faith and not of policy measures (Valdés 1972: 423)). We should also recall that he is a contemporary of the vociferous leftist muralists (Orozco, Siqueiros, Rivera), as well as of a cosmopolitan generation of brilliant poets and essayists such as Salvador Novo and Alfonso Reyes (a politician and translator of Classical languages, who publicly claimed Latin for the Left ${ }^{1}$ ), whose ideological counterpoint he represents.

Although he was a prolific translator of Greek, Latin and Hebrew, Garibay is known and praised for having bestowed Nahuatl writings the literary status and having placed them among the classics of world literature, thanks to his translations of numerous texts that had been forgotten or precariously studied. As such, and through the continued recovery and appropriation of his works by nationalist anthropology, led by Mexican scholar Miguel León-Portilla, his "amartelado discipulo" (infatuated disciple) (Valdés 1972: 429), Garibay is still the reference for any scholar interested in Nahuatl language and literature, and, therefore, for Mesoamericanists in general.

Garibay is a Christian Humanist: "No comprender al hombre y no esforzarse por comprender a todos los hombres es lo más opuesto que hay al verdadero humanismo. Tenemos que agregar que la base del Cristianismo es la comprensión universal de todos 
los hombres" (Garibay 1953, I: 207), he says. This unifying vision is also visible in the prefaces to his Greek translations ${ }^{2}$, as well as in his commentaries to Nahuatl texts ${ }^{3}$, where he upholds the universal values of poetry and predicates convergences between Greek, biblical and Hindu traditions. But, above all, he admires classical Greek culture: “...el teatro griego es fundamental para las raíces de nuestra cultura” (Garibay 1962: XXII). It is only natural, therefore, that this would be the "universe of representation" dominating his translation work.

In his celebrated Historia de la literatura náhuatl (1953), he presents a selection of extracts translated from Cantares Mexicanos alternating with explanations, in a format recalling a classical literary inventory, or "recensio." This alternance helps us follow Garibay's preferences, irritations and reluctances. Indeed, although he doesn't present a systematized reflection about translation (translation is not problematized in the way rhetorical or stylistic aspects are), the tenets are not difficult to identify. ${ }^{4}$

His translation production is voluminous and he often retranslates the same texts. In his work, translation is an instrument of a greater purpose: to create and disseminate a great literature. Stressing the analogy between Greek and Nahuatl, he says in his Historia de la literatura náhuatl that, just as there are many ways of translating Horatio, there are many ways of translating these texts (Garibay 1953, I: 500). More than ten years later, in his bilingual corpus Poesía Náhuatl, he still refers to "la variedad de mis traducciones que me han inculpado" (Garibay 1965, II: LVI), noting that he has been criticized for the "inconsistency" of his translations.

In Garibay, the many references to the temporary, provisional nature of his versions do not seem to come either from modesty or from a sense of calculation. Indifferent to pressures from his readership to render a fixed translation, he forces the texts to surrender through repeated translation assaults. He seems convinced that only in this way will the Nahuatl texts yield their beauty and meaning. This open position offers a safe harbor for his multiple versions. He claims that his work is provisional but he is also able to account for his translations.

Garibay is an advocate of free translation, and most of the time he adapts the texts to an idealized concept of literature. His hermeneutic approach is idealist, positivist: "La versión no es calca, sino transfusión de vida..." (1965, II: LVI). ${ }^{5}$ For him, in spite of their obscurity, these texts contain a meaning: "En toda composición poética hay asunto, por vago e insustancial que suponga” (Garibay 1964: XVII), and he classifies this "matter" in three categories: divine, human, and philosophical questions (Garibay 1964: XVII-XXVII). The texts - which he considers poems - contain therefore no less than the explanation of a whole cultural universe.

And Garibay must make this universe intelligible. To this end, there being no model for these texts in the target culture, he will resort to the Greek models. Obviously, he will have to submit the texts to a process of normalization; that is, they will be standardized and forced into a literary canon. I would say, furthermore, that this is a case of apologetic translations: they have been entrusted with the task of representing a great civilization, comparable to the classical ones. They will therefore have to be classical too.

In the treatment of texts through translation, particularly in the versions of Cantares mexicanos, we can see how most of the time Garibay dissolves ambiguities: he eliminates all Christian references and generally removes whatever doesn't meet 
his stylistic, chronological or ideological assumptions. In his translation approach, precedence is given to meaning over letter. He disentangles obscurities, adding clarity and formal beauty. He chops up the text according to formal versification and introduces rhythm. Language is homogenized and systematized according to the norms of Greek drama. At the level of the whole corpus, Garibay gives coherence and cohesion to a heterogeneous corpus, and rationalizes it according to literary canons, which themselves derive from Greek canons. Moreover, he characterizes it according to his moral and aesthetic values. ${ }^{6}$

Whatever flaws we may find today in his work, Father Garibay's work was undoubtedly, as Keen says: "the first large-scale, rigorously scientific exploration of a subject that swarmed with difficulties because of the obscure, hermetic character of much of the Nahuatl literary material" (Keen 1971: 535). His translations, published in two capital works ${ }^{7}$ and a host of smaller, popular, editions, allowed him to posit the existence of a genuine Nahuatl literature at a time when things having to do with Indians were mostly despised.

\section{León-Portilla: translated literature becomes historiographical source}

Meanwhile, Miguel León-Portilla (born 1926), Garibay's disciple, proposed in his doctoral thesis (1956) that these writings, some translated by his master Garibay and others by himself (and León-Portilla will never be absolutely clear about that), together with the ancient codices and paintings, could support the notion that, contrary to what was commonly assumed, there existed in pre-Columbian times a corpus of abstract knowledge that could be considered as Nahuatl Philosophy. His tenets were tremendously successful, and his doctoral thesis: La Filosofía Náhuatl estudiada en sus fuentes, has been reedited at least eight times. ${ }^{8}$ Not only is LeónPortilla a prolific writer, who has edited and published studies based in these translations of ancient texts, now unavoidable sources for historians and anthropologists, he also directs a Nahuatl study group (Seminario de Literatura Náhuatl) at the Universidad Nacional Autónoma de México that has been the spawning ground for many Nahuatl specialists, and presides over the field from the watchtower of the journal Estudios de Cultura Náhuatl, founded by him and now directed by philologist Ascensión Hernández de León-Portilla, his wife. Moreover, he has also directed the Academia Mexicana de la Historia (1996-2003). Among other international nominations, he was head of the permanent representation of UNESCO in Mexico. He has been acclaimed at home and abroad, and has received many awards and acknowledgements. He moves freely in a vast territory encompassing history and anthropology, philosophy, philology, and literature. Excerpts of his (or Garibay's?) translations are engraved in the monumental façades of Mexico's National Museum of Anthropology. He represents official Mexican history and its ideologeme: the splendor of the Aztec past.

This knowledge about the past has been at least partly brought about by translation. And while in Garibay the translation effort and details of the transfer operations are quite explicit, in León-Portilla we do not find anything of the kind. Appropriation through citation is his strategy. We can seldom see original and translation together 
and, in his essays, translations are cited as if they were originals. Translation is not problematized in spite of the acknowledged tremendous difficulties involved in the interpretation of Classical Nahuatl.

In short, once classicized by Garibay, the translated texts have been used to promote the Aztec archetype which has become the brand name for Mexican culture of the 20th century and one of the pillars of nationalist thought and policy. In a progression facilitated by translation, texts move from obscurity to classicization (Garibay) and then to aztequization (León-Portilla), becoming fixed as true sources of the "ancient word" (to use a favorite term coined by León-Portilla) and acquiring a sacred, canonical, status (which maybe they never had in their time) that should protect them from mishandling and misreading.

This is why translations made by other scholars, or interpretations derived from them, have been fiercely attacked by León-Portilla. He has used linguistic erudition as the main weapon, but his aggressive reactions suggest that the stakes could be higher than the mere linguistic controversy, as important as it undoubtedly is. It becomes obvious that translation is indeed a powerful tool in the hands of the historian since León-Portilla seems to consider this tool dangerous in the hands of other historians, when there is a risk of other, "deviant," translations, which would upset the canonical representation of the past that his use of translation has authorized.

I have traced the sequence of a controversy that opposed León-Portilla to his critics, hoping that it will explain and illustrate the significance of this risk as well as the relationship it sustains with translation. I will refer to Garibay/León Portilla, as a complex, when refering to translations or representations brought about by the association of both. Otherwise, their names will be mentioned individually.

\section{Some challenges to Mesoamerican history as brought about by Garibay/León-Portilla's translations}

León-Portilla's La filosofía náhuatl estudiada en sus fuentes was published in 1956, in a format very much reminiscent of Garibay's 1953 Historia de la literatura náhuatl (i.e., alternating selections of translated excerpts with explanations). As far as I can tell, it was the indisputable reference for scholarly work for many years. ${ }^{9}$ Then, in 1985 and 1989 two books were published which represented important shifts in the perception of Mesoamerican studies: John Bierhorst's first English version of Cantares Mexicanos, and Amos Segala's La littérature náhuatl: sources, identités, représentations. Bierhorst's translation is a radical departure from Garibay-LeónPortilla's ideas, and Segala's analysis, drawing from Bierhorst's version (without however vouching for it), points directly to the problem of translations as instruments of representation of the Aztec past. Each in its own way, these works constitute a direct challenge to the "official" history, in that they assume the need for new readings of the Classic Nahuatl texts. ${ }^{10}$

Then, in 1992, Serge Gruzinski's La colonisation de l'imaginaire. Sociétés indigènes et occidentalisation dans le Mexique colonial was published. These excerpts ${ }^{11}$ from the introduction illustrate the contentious nature of the problem:

[...] l'archéologie et l'histoire préhispaniques ont souvent oublié que la plupart des témoignages qui concernent l'époque précortésienne furent élaborés et rédigés dans le 
contexte bouleversé de la Nouvelle Espagne naissante et qu'ils offrent avant toute chose un reflet de cette période.

[...]

On regrettera qu'abondamment exploités par les archéologues et les historiens pour décrire les "religions," les sociétés, les économies anciennes, ces textes aient moins souvent servi à éclairer le monde qui les a inspirés et qui était déjà christianisé et acculturé lors de leur mise en forme.

Gruzinski opens fire against the essentialist historiography which in its search for a monolithic truth about the past forces interpretations upon the sources. It is a double criticism: against the fact that the historian "forgets" that the texts are themselves constructions and that he sacrifices them on the altar of "authenticity" (the true Aztec civilization, the true past):

L'ensemble de ces domaines de recherche s'articule, on l'aura compris, autour d'une réflexion qui cherche moins à pénétrer les mondes indigènes pour en exhumer une "authenticité" miraculeusement préservée ou irrémédiablement perdue qu’à prendre la mesure sur trois siècles d'un processus d'occidentalisation dans ses manifestations les moins spectaculaires mais peut-être aussi les plus insidieuses.

A second dissident voice belongs to a former student of León-Portilla's: Jorge Klor de Alva. In his volume on Friar Bernardino de Sahagún, the 16th century Franciscan ethnographer (to which León Portilla was invited to contribute alongside proponents of the new approaches), Klor stated: “...with notable exceptions (Tedlock 1983; Todorov 1984), Mesoamerican studies have remained at the margins of the current debates on the epistemological foundations of the human sciences and the relations between narrative discourse, representation, and meaning" (Klor de Alva 1998: 31) and specifies that by virtue of the "crisis or representation" represented by these debates:

[...] fully objective descriptions or "translations" of cultural reality, where the narrative or image and the referent have an unmediated and transparent relation, are either fundamentally problematic or not possible at all. Therefore, encompassing theories and overarching paradigms that contend that their methods yield such descriptions must be rejected as deceptive. (Klor de Alva 1998: 32)

With varying degrees of emphasis, and from different angles, both Gruzinski and Klor voiced the need for new ways of seeing the Aztec past, and in so doing, they pointed to the problem of "the sources," their translation and interpretation. The work of León-Portilla, while recognized as pioneering and fundamental, is the (not always explicit) target of the criticisms expressed by these authors. More generally, their analyses constituted a clear departure from the traditional positivist and essentialist historiography which, in the canonical version of the Mexican pre-Conquest history, confuses the past with its traces, referent and reference, thereby creating an illusory image, a sort of trompe l'oeil.

\section{Reactions to the challenges}

Miguel León-Portilla answered in two modes: against Bierhorst and Segala he reacted offensively, writing two ruthless pieces ${ }^{12}$ : in 1986, “¿Una nueva interpretación de los Cantares Mexicanos? La obra de John Bierhorst,” and in 1991, “¿Una nueva aportación 
a la literatura náhuatl? La obra de Amos Segala." The sarcasm of the titles ("A new interpretation?, "a new contribution"?) needs no stress.

To respond to Gruzinski and Klor, he reacted in a more defensive tone, but missing no opportunity to make his position known. In 1992, he writes in English: "Have we Really Translated the Mesoamerican Ancient Word?"; in 1993 he includes an appendix to the 7th edition of his La filosofía náhuatl, estudiada en sus fuentes, entitled “ ¿Nos hemos acercado a la antigua palabra?," and takes up the subject again in Quince poetas del mundo náhuatl in 1994. Finally in 1996 he publishes a volume totally dedicated to the defense of his position: El destino de la palabra. De la oralidad $y$ los glifos mesoamericanos a la escritura alfabética, in which the 1992 article "Have we Really Translated..." appears translated into Spanish (by himself) as the first chapter of the book. In a tone that goes from complaint to self-righteousness, in at least four publications, he tries to defend the notion that, in spite of the colonial filters, the "ancient word" has survived and resounds today as strongly as it did before the Conquest, both because it was predestined to survive and thanks to his work as a translator. His defense strategy consists in a tactical misreading of the criticisms: he eschews the attack by challenging the critics to question the "authenticity" of the texts (placing himself as the "priest" who has been endowed with their protection). The texts thus become sacred and the critics are therefore seen as iconoclasts.

I do not know whether Gruzinski and Klor took up the matter again. I am inclined to think that they went about their businesses and abandoned the controversy altogether. As for Bierhorst, I have not found any reply to León-Portilla's pounding attack, but his work was received with interest and appears in the bibliographical lists of university curricula and study groups in the United States ${ }^{13}$ (although not in Mexico, where it has not been translated). ${ }^{14}$ Amos Segala replied to the 1991 attack, mimicking León-Portilla's rhetoric style in the title of his article: "La literatura náhuatl, ¿un coto privado?" [a private hunting ground], to which León-Portilla responded in a brief and sharp: "A modo de comentario" apparently closing the discussion. However, in 1995, León-Portilla's friend and colleague Georges Baudot relayed him with renewed gusto in his inaugural speech at the Academia Mexicana de la Historia, "La palabra del México antiguo en su camino hasta nuestros días." There he enfonce le clou proclaiming not only that indeed the "ancient word" has been truthfully transmitted, but that those who do not think so are neocolonialists [sic] who would have preferred that it disappear. Moreover, he said, they have no intellectual authority because they do not know Nahuatl (Baudot 1995: 138).

So, in defending his translation he is also defending a historiographical paradigm, that of a positivist and objective history-making, garnished with a progressive, antiimperialist aura, a combination of conservative and progressist ideas which is also to be found extensively in Mexico's political discourse after the Revolution and all through the 20th century.

\section{The stakes}

The problem is then at least partly about translation, both about cultural translation and about "our" interlinguistic translation: two different languages and five centuries between the authors and the interpreters. And there must be tremendously important things at stake, for in his criticism to Amos Segala's work, León-Portilla wishes 
that it had not been translated and published ${ }^{15}$. Also James Lockhart, a renowned anthropologist, in his more balanced criticism of John Bierhorst's work, ends up by voicing his apprehension: "although the book is a great boon to Nahuatl scholars [...], in the hands of the uninitiated, who will constitute the majority of its readership, it may do more harm than good, mislead more than instruct" (Lockhart 1991: 157).

New readings are threatening to León-Portilla, who has candidly acknowledged it in his defensive writings, both in Spanish and English: if it is "not only naïve but extremely dangerous" to think that the old Nahuatl texts "can be trusted as true preHispanic testimonies," then "what can we say, those of us who believe we were translators of the ancient word? Will it be worthwhile to try to retranslate 'the texts' in view of such a new understanding of how they were obtained and what they conveyed?" (León-Portilla 1992: 315-316). Elsewhere he plaintively says that the notion that the texts were already contaminated by successive filters means that he may have "bordado en el aire" (León-Portilla 1997: 398), i.e., that his efforts were illusory, like embroidering in the air.

He is personally concerned, and rightly so, but ultimately, if we are to believe his critics, what is at stake seems to be a political issue, linked to nationalist ideologies:

El valor simbólico de la literatura náhuatl ha sido muy importante para la definición de la identidad mexicana. Todo cuestionamiento de sus contenidos, de su realidad específica y de su mensaje se relaciona ahora con un crimen de lesa patria que pocos especialistas e historiadores de la cultura mexicana están dispuestos a enunciar (Segala 1990: 27)

Indeed, one of the pillars of what we call a national identity (of any nation, for that matter) is the consensus about a common past. In the Mexican case, it is the Aztec past that has been chosen to represent this common heritage (Gutiérrez 1999) and León-Portilla's translations and interpretations have helped consolidate and disseminate this notion.

Cornered, no doubt, by León-Portilla's savage criticism, Segala speaks out: the new interpretations carried out by modern Náhuatl textology hold the potential to invalidate all of León-Portilla's research (Segala 1992: 209). If indeed it is so, this would explain the acrimony of the controversy and León-Portilla's call for censorship of other translations. ${ }^{16}$

\section{The crux of the matter}

The controversy over the Náhuatl sources unfolded, as we see, in two related arenas: historiography and translation. In the historiographical arena we are witnessing the conflict over the authenticity of the sources. Opposing Carrasco (see footnote 10), Gruzinski and Klor de Alva, we have León-Portilla's optimistic notion that the sources are authentic, i.e., pre-Columbian, yielding true accounts of "the Aztec past" through his intermission: "la palabra indígena no ha muerto; nuestro destino ha sido proseguir en su rescate” (León-Portilla 1994: 146).

And then, the translation arena: the controversy is about the way in which these texts are translated and used today by the historian himself and about what historical interpretations these translations convey. This aspect of the controversy has a greater 
potential for conflict, since the problems posed are not abstract and distant; it is in the materiality of the translated text that the questions arise. Garibay-León-Portilla's translations constitute the basis of what is considered the "official" version of the Aztec past, and this version has been challenged. Let's have a look at some material points of controversy with regard to the Cantares mexicanos, a corpus of texts transcribed into alphabetical Nahuatl around 1550, excerpts of which were translated for the first time by Garibay (some of them at least three times in different publications), and used by León-Portilla, who claims to have done some of the translations himself, as I noted before, although it is seldom clear which translations are his and which are Garibay's. The new translation and interpretation undertaken by John Bierhorst in 1985 is accompanied by the Nahuatl text. Being the first complete transcription ever attempted, it constitutes in itself a great step forward.

\section{Garibay/León-Portilla's translations authorize the notion that there existed a clique of wise men opposing the Aztec militarism and the rituals of human sacrifice}

This criticism is based on the interpretation of the word tlamatinimeh (or tlamatinime). As explained by Segala (Segala 1990: 73), it could be interpreted as an adjective meaning "wise" or as a substantive: "the one who knows." León-Portilla, following sixteenth century ethnologist friar Sahagún, who said that tlamatinimeh were philosophers, promoted the word and made it designate a class of sages who opposed the militarism of the Aztec and had developed a sense of philosophical inquiry comparable to that of ancient Greece. The Cantares mexicanos collection contains poems or songs that Garibay and León-Portilla attribute to these sages. They interpret the pessimism manifest in the texts as a sign of metaphysical malaise as well as a rebellion against the Aztec hierarchy. As Keen ironically points out, this suggests that, "in an atmosphere of refinement and luxury comparable in some respects, perhaps, to that of princely courts of renaissance Italy, discussions of aesthetics and metaphysics were held" (Keen 1971: 40). Based on this translation of the word (biased according to Keen, Segala and Bierhorst), León-Portilla seems to have built "toda una teoría de la civilización literaria azteca, basada en una supuesta dialéctica conflictiva entre los ideales y rituales del sacrificio humano y las dimensiones existenciales estéticas teorizadas por los Tlamatinimeh" (Segala 1991:211). Based also on this notion, LeónPortilla claims to have identified the names of some of the authors of the songs, who were kings of some of the major cities tributary to the Aztecs. Segala contends that the notion of individualism (the artist as a visible subject) cannot be argued for Aztec society, in which all manifestations were strictly ritualized. Moreover, such titles as "The song of Neçahualcoyotl," according to Bierhorst, should be understood as "The song about Neçahualcoyotl” (Bierhorst 1985: 101), a translation that would invalidate the official theory, so dear to León-Portilla, about the existence of poet-kings.

\section{Garibay/León-Portilla's translations pre-date the originals}

Following his mentor Garibay, León-Portilla considers that the Cantares Mexicanos is a collection of transcriptions of mostly pre-Hispanic origin. Comparable to the philosophic and religious thinking of India and Greece, according to him, they are 
“una vena riquísima para reconstruir la visión filosófica de los nahuas" (León-Portilla 1997: 17) and were translated by Garibay and himself accordingly. Confirming Garibay's declared opinion that any Christian references in the texts were aberrant corrections introduced by the original scribes (León-Portilla 1997: 17), the texts were purged of all occurrences of words like "Dios," "Santa Maria," "Obispo," "Espiritu Santo," and interpreted as an expression of the aesthetic vision of the tlamatinimeh. Bierhorst points to several examples where the text was read in such a way that Spanish references disappeared, such as in the case of the word tonxihuan being translated as "grandson" (tixhuihuan or toxhuihuan) instead of "don Juan" (ton Xihuan), a translation that would have revealed the post-Conquest origin of the text (Bierhorst 1985: 121). In León-Portilla’s Filosofía náhuatl I have found several fragments where references including the word "Dios," in Spanish in the Náhuatl text, have been removed with no explanation, and one instance in which, as I will show later, "Dios" becomes the pre-Hispanic god Ometéotl. Garibay's approach is not consistent: in his Poesía náhuatl he removes such references and places them as bracketed omissions, while in his Historia de la literatura náhuatl, he explains why he omits them altogether in the book. David Damrosch, in an illuminating article on the aesthetics of the Spanish Conquest, explains: "Very often, the names of God (Dios, or Tios, or Tiox) and other Christian figures appear in the manuscripts, and here too it is hard to say how often these names reflect the poet's own beliefs, or a deliberate ruse on the poet's part to escape censorship, or a pious emendation by the native informants who collected the songs...." ${ }^{\prime 7}$ In this ambiguity lies the possibility of differing interpretations.

Regarding the dating of the texts, John Bierhorst believes that "by far the greater number belong to the post-Conquest period. These deal mainly with the Conquest itself or its aftermath, preserving all the old imagery now adapted to the crisis at hand" (Bierhorst 1985: 4). For him, these are esoteric texts that serve to ritually summon hosts of ghost warriors that will establish a paradise on earth "in which Mexicans, while embracing Christianity, will enjoy superiority over Spanish colonists..." (Bierhorst 1985: 4). These rituals, according to Bierhorst, were performed as part of a revivalist movement that would have taken place in mid-sixteenth century. He recognizes that at least one song ("Song of cloud companions," in p. 84) could be an antecedent for the rest of the songs, but in general he considers them just as new as the songs of North American Peyote Cult (Bierhorst 1985: 106). León-Portilla opposes this view, based in his own interpretation of the authorship of the songs. Clearly, by asserting that they were composed by poet-kings, he is saying that they are pre-Hispanic. ${ }^{18}$

\section{Garibay/León-Portilla's translations serve the notion of an Aztec aesthetic vision based on a poetic, "flower-song," dubious ideal}

An important characteristic of the Náhuatl language is the rhetorical form Garibay called "diphrasism," that is, the lexically fixed co-occurrence of two words metaphorically meaning a third thing. For instance: in cueitl in huipilli, literally the skirt, the blouse, has been interpreted as meaning "woman," in nontlan in itzcatlan, place of silence and cold: "region of the dead." In the same way, in xochitl in cuicatl, the flower and the song, was interpreted by Garibay, ${ }^{19}$ and then by León-Portilla, as the epitome of the Náhuatl aesthetics, an idealized representation of arts and poetry, "lo unico 
verdadero en la tierra" (León-Portilla 1997: 178). Only a selective reading of these poems, as pointed out by Damrosch, allows for such a harmonious view of Aztec aesthetics (Damrosch 1993: 142). In fact, many of the poems are inextricably linked to the violence of wars and human sacrifice.

Bierhorst turns away from the flower-harmony view and focuses on the warfare aspect of the poems by proposing a totally different explanation: the Cantares mexicanos are a collection of "ghost-songs": "musical performance in which warriorsingers summon the ghost of ancestors in order to swell their ranks and overwhelm their enemies. [...] in response to the music, ghost warriors from paradise, led by ancestor kings, supposedly came 'scattering', 'flying', or 'whirling' to earth in the form of flowers or birds...” (Bierhorst 1985: 4) Recalling other American traditions, particularly from North American indigenous groups, he states that it is these dead warriors who are metaphorically called flowers or songs. The singer travels to the other world to bring back these flowers and songs, in a process that according to Bierhorst, is "reminiscent of the shamanistic trans journey." This interpretation has been ridiculed by León-Portilla in a style and tone that suggests that Aztec philosophy leaves no place for such frivolities. ${ }^{20}$ Nationalist prejudices may also have played a role in León-Portilla's response, notably the fact that a great civilization such as the Aztec could be related to North American nomadic tribes (the prejudice being twofold: because of Mexico's mixed feelings about its powerful neighbor and because of the less prestigious nomadic tribes), but this is only speculation on my side.

\section{Hiding translation:}

\section{León-Portilla has not explained how he has translated}

The fact that León-Portilla has not given a critical edition of his translations has been highlighted at least by Amos Segala and, indirectly, by Bierhorst who, although he is not a Nahuatl specialist (his field of study is the North American Indian peoples), has proposed a new reading of the Cantares mexicanos and presented a careful edition of the Nahuatl text with a face-to-face translation, accompanied by annotations. LeónPortilla usually offers fragmented versions, extracted from their contexts and used to illustrate his argumentations, often without confronting texts ${ }^{21}$. His translation paradigm is that of transparency, of denial of transfer. The texts are supposed to speak for themselves. To bring about this result the historian metamorphoses himself: he becomes half historian and half translator, and the historian half dictates what the translator half will produce. The translator half has no will, and therefore may be said to be an empty, neutral, carrier. The image of the ventriloquist can be also recalled as a simile.

When he argues for the existence of philosophical knowledge among the Nahua peoples, he defines what philosophy is and rhetorically asks:

¿tenemos pruebas ciertas de que tal inquietud [the philosophical concern] y afán hayan aparecido entre los nahuas? ¿hubo entre ellos quienes empezaran a dudar de los mitos, tratando de racionalizarlos, hasta llegar a plantearse en forma abstracta y universal cuestiones como las arriba mencionadas?

Con base en la evidencia de los documentos nahuas emanados al tratar de las fuentes, nuestra respuesta es decididamente afirmativa. Los textos originales libres de toda interpretación que pudiera falsear o desviar fantásticamente su sentido, irán apare- 
ciendo a lo largo de este estudio, hablando por sí mismos. Confesamos, desde luego, que la versión castellana que de dichos textos daremos, no obstante ser escrupulosamente fiel, difícilmente alcanzará a mostrar la maravillosa concisión y lo matizado de la lengua náhuatl. (León-Portilla 1997: 56) [the stress is mine].

Here we can see, condensed and linked together, the historiographical and the translation ideological orientations. We know where the translation ideology comes from. Barthes, in turn, will tell us the origin of the historiographical paradigm to which León-Portilla belongs:

L'histoire semble se raconter toute seule. Cet accident a une carrière considérable, puisqu'il correspond en fait au discours historique dit "objectif” (dans lequel l'historien n'intervient jamais). ... Au niveau du discours l'objectivité - ou carence de signes de l'énonçant - apparaît ainsi comme une forme particulière d'imaginaire, le produit de ce que l'on pourrait appeler l'illusion référentielle, puisque l'historien prétend laisser le référent parler tout seul. ${ }^{22}$ [the stress is mine]

We could, then, posit that León-Portilla is more a product of a certain historiographical paradigm than a naïve or deceitful historian or translator. Nevertheless, one cannot but smile at the blunt assertion that his translation is "scrupulously faithful" when he not only chooses to remove references to "Dios," that could reveal the postConquest origin of the text without explanation but goes as far as substituting the word Dios in the original Nahuatl for the Aztec god Ometeotl, as I show in the text box.

\begin{tabular}{|c|c|c|c|}
\hline $\begin{array}{l}\text { Cantares } \\
\text { mexicanos, } \\
\text { fol. 35v. }\end{array}$ & $\begin{array}{l}\text { John Bierhorst } \\
\text { (1985: 248-249) }\end{array}$ & $\begin{array}{l}\text { Ángel María Garibay } \\
\text { (1968: 86) }\end{array}$ & $\begin{array}{l}\text { Miguel León-Portilla } \\
\text { (1997: ? y 213) }\end{array}$ \\
\hline $\begin{array}{l}\text { Transcrip- } \\
\text { ción náhuatl }\end{array}$ & $\begin{array}{l}\text { Can ompa nonyaz huiya } \\
\text { can ompa noyaz aya ome } \\
\text { ycac yohui yohui yehuan } \\
\text { Dios huiya amach } \\
\text { temochia ompa ximoaya } \\
\text { ail.ytec y çanican y yehua } \\
\text { yece ximoaya in tlpc. Y } \\
\text { ohuaya Et. }\end{array}$ & $\begin{array}{l}\text { Can ompa nonyaz, Huiya } \\
\text { Can ompa nonyaz? Aya } \\
\text { Omeicac yohui yohui ( ) } \\
\text { (Om. yehuan Dios) } \\
\text { A mach temochan ompa } \\
\text { Ximoayan } \\
\text { A ilhuicatl itec in zan nican } \\
\text { Ye Ximoayan in tlalticpac. } \\
\text { Ohuaya Ohuaya. }\end{array}$ & $\begin{array}{l}\text { El camino hacia el dios de la } \\
\text { dualidad } \\
\text { ¿can ompa monyaz? } \\
\text { ¿Can ompa nonyaz? } \\
\text { Icac iohui iohui Ome Teotl } \\
\text { ¿A mach te mochian ompa } \\
\text { Ximoayan? } \\
\text { ¿A ilhuicatl itec? } \\
\text { ¿In zan nican yehuaya yece } \\
\text { Ximoayan in tlaltipac. } \\
\text { Ohuaya? }\end{array}$ \\
\hline Traducción & $\begin{array}{l}\text { Then where am I to go? } \\
\text { Ah, where am I to go? } \\
\text { God stands two places! } \\
\text { Aren't you awaited there } \\
\text { beyond, where are all } \\
\text { shorn? No, it's not within } \\
\text { the sky. The place where } \\
\text { all are shorn is here - on } \\
\text { earth! }\end{array}$ & $\begin{array}{l}\text { Incertidumbre del fin } \\
\text { ¿A dónde iré, ay? } \\
\text { ¿a dónde iré? } \\
\text { Dónde está la Dualidad... } \\
\text { ¡Difícil, ah, difícil! } \\
\text { ¡Acaso es la casa de todos } \\
\text { allá } \\
\text { donde están los que ya no } \\
\text { tienen cuerpo, } \\
\text { en el interior del cielo, } \\
\text { o acaso aquí en la tierra es } \\
\text { el sitio } \\
\text { donde están los que ya no } \\
\text { tienen cuerpo! }\end{array}$ & $\begin{array}{l}\text { ¿A dónde iré? } \\
\text { ¿A dónde iré? } \\
\text { El camino del dios de la } \\
\text { dualidad } \\
\text { ¿Acaso es tu casa en el sitio } \\
\text { de los descarnados? } \\
\text { ¿en el interior del cielo? } \\
\text { ¿o solamente aquí en la } \\
\text { tierra es el sitio de los } \\
\text { descarnados? }\end{array}$ \\
\hline
\end{tabular}


It is useful to compare the three versions to illustrate the difference between, first, the transcription and translation approach chosen by Bierhorst and that of Garibay and León-Portilla, and then between Garibay's and León-Portilla's individual approaches.

A great divide in interpretation can be seen in the differing transcriptions: Bierhorst, who considers the text as invocations to the spirits, maintains the linear original handwriting, while Garibay and León-Portilla, for whom the text is a sample of high culture and literary quality, organize it in verses. Bierhorst scrupulously reproduces all the vocalizations (eight); Garibay keeps most of them (seven), and León-Portilla keeps only half (four). Bierhorst keeps the Christian reference to God (Dios); Garibay observes its omission in parenthesis, signaling the place where it belongs, while León-Portilla does not see any impediment to substituting a Christian reference for a Nahuatl one (Ometeotl or Ome Teotl) ${ }^{23}$. He also includes a title of his invention: The path towards the god of duality.

In the translation, none of them includes the vocalizations (aya, oya, etc...). Bierhorst takes ome(icac) as the cardinal "two" and translates "Dios" as "God." Garibay eliminates "Dios" and promotes the word ome to represent the metaphysical concept of "duality." He also includes here a title of his creation: The incertitude of the end. León-Portilla, of course, having altered the original, which now reads Ome Teotl, translates it as the Aztec "god of duality."

In case we are tempted to think that León-Portilla misinterpreted the word "Dios," let's read what he has to say in the interpretation of the fragment: "Pretenden saber los tlamatinime cuál es el camino que lleva a Ometéotl (dios de la dualidad), como aqui explícitamente es designado" (the stress is mine) (León Portilla 1997: 149). Some fifty pages later he uses the same citation and explains: "Analizando brevemente el poema, se verá que su planteo de la cuestión es perfecto: sabiendo que "hay que irse" se busca el camino que pueda llevar a la vida, a Ometéotl...” (León-Portilla 1997: 213). There is no reason why León-Portilla would replace the Christian "Dios," unless his purpose is to "nahuatlize" the text. Logically, this minute but most significant operation, concealed by the fact that 1) there is only one original manuscript, 2) the reader cannot but rely upon the historian's transcription, and 3) the transcription does not confront the translation (not to say other transcriptions) and creates a phenomenal effect: it rockets the text back to pre-Hispanic times, and, by doing so, it confers "authenticity" to it, a pureness existing only in the will of the historian-translator.

\section{Conclusion}

The best way Father Garibay knew of to "vivify" Nahuatl texts was repeating their translations. The text in question (see box) also appears in two different passages in his Historia de la literatura náhuatl (without Nahuatl transcription in any). In page 89, he translates:

“¿Dónde es donde he de ir? ¿Dónde es donde he de ir?

¡El camino, el camino está presente del Dios de la Dualidad!

¿No acaso todos hemos de ir al Descarnadero?

¿Es dentro del cielo, o es en la tierra este Descarnadero?”

and in pages 196-197 of the same book, with no apparent reason, he translates again: 


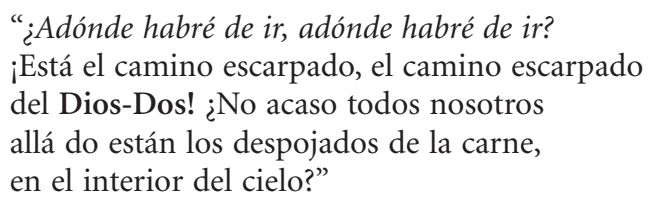

As illustrated above, he did hesitate between the two alternatives: "God of duality" or "God-two" (more classic or more exotic). That was in 1953. In 1956, León-Portilla adopts "God of duality," touches up the original text and sends it to a virtually untraceable annex. Successive editions repeat the maneuver endlessly.

The traces that the translator leaves behind are visible. Garibay's traces are easy to follow. In a way, his work was a sincere effort to unveil a literature so far unknown and marginal. His chrestomatic versions illustrate a quite open conversation with the texts about what they are or might have been. If his efforts can be branded as translations-introductions in the Meschonnical sense, they are nevertheless not deceitful: he sincerely assumes the Greek model for a mid-20th century Mexican reader, and he repeats his attempts to force the texts to speak. ${ }^{24}$

And here is the most important distinction to be drawn. We have been accustomed in Mesoamericanism to see Garibay and León-Portilla in association. But the Garibay/León-Portilla complex requires revision and differentiation. León-Portilla wraps himself in Garibay's banner, quoting and using his writings as auctoritas, but the translations thus produced and disseminated by him no longer belong to literature, nor are they infused with literary vital energy, as Garibay wanted them to be. They have become part of the heavy burden of official history, which has materially restricted the possibilities of revision. The consequences of this fixation are far from innocuous.

It is difficult to overcome a certain sense of irritation when considering the maneuvering needed to bring about such translations and to defend them from external as well as internal opposition. Garibay's translations were part of a bold endeavor, and his frankness and sincerity is definitely "disarming" (in the introduction to his La llave del nahuatl, he invites good faith critics to write to him at his personal address, which is given in page 16) while León-Portilla's work is definitely embedded into the hegemonic discourse, deploying a whole defensive apparatus. True, there is the humanistic design: the need to construct a memory of a common past, a grandiose past, comparable to the greatest pasts on earth: the Mediterranean, the Orient (somebody called the Aztec poetry the Rig Veda Americanus)..., but there is also a perhaps unintended complicity with the factual powers for which this particularly constructed memory of the past is a convenient way of escaping responsibilities with contemporary indigenous peoples. In other words, a past dangerously close to - or at least readily convertible into - a theme park.

When, in 1969, Octavio Paz proposed to undertake the "criticism of the pyramid," ${ }^{25}$ he was pointing to the symbolic link between nationalist anthropology and Mexican politics. Then President Díaz Ordaz had sent the army to violently repress a peaceful demonstration at the Tlatelolco Square in Mexico City (October 2, 1968). Paz drew an accurate parallelism between, on the one hand, the figure of the President and the Aztec king (tlatoani), and, on the other hand, between the prevalent political one-party structure the Aztec pyramid. Translations, disseminated in popular and scholarly editions, filtered through the collective thinking from the first history 
classrooms, played a role in the construction of nationalist anthropology, the political pyramid, and its maintenance.

This is, however, a belated discovery (if at all). New generations of Mesoamericanists (López Austin, among others) are approaching the task of translation differently and we are witnessing serious attempts to approach it with more caution than was previously exercised. However, it would be naïve to think that this change comes solely from the historian's side or that it is the result of one side of the controversy winning the battle. While we have witnessed a change of historiographical paradigm that has marginalized the old positivist, essentialist erudition, other apparently unrelated factors are also playing a role: on the one hand, Mexico's proverbial nationalism has had to be reshaped in the light of recent social, political and economic events, most prominently its belonging to a free-trade area with its North-American neighbors since 1994; on the other hand, the concomitant irruption of the indigenous peoples into the public arena and the defeat of the long time ruling party (2000) have also shaken the traditional grounds on which the concept of nation was built after the Mexican Revolution. The Aztec archetype (a symbol for aggressive nationalism set against the overwhelming presence of the United States) is crumbling and a new one appears to be emerging. The Maya cultures, wrapped in the mystery of their sudden disappearance, are apparently far less aggressive, their predominantly skyblue color contrasting with the Aztec's sharply outlined red and black, their sites greener and landscapes softer than the arid highlands of the Aztecs, their aesthetics gentler and less controversial. In this shift of interests, there is more room for revisions of the old paradigm, which includes its translations.

But this is another story...

\section{NOTES}

* This essay concludes research undertaken within the context of the Ph.D. Seminar at the University of Ottawa which produced two papers: "El historiador y la traducción: una curiosa amistad," presented at the XII Encuentro de traducción literaria, in Mexico City, October 2002, and "La traducción como representación: Grecia en el Anáhuac," presented at the I Congreso Sudamericano de Historia, Sta Cruz, Bolivia, August 2003.

** I am using "historian" as a generic, whatever the academic credentials of the practitioners. In this sense, Garibay, a Churchman, and León-Portilla, who holds a Ph.D. in Philosophy, act as historians

1. "Quiero el latín para las izquierdas, porque no veo la ventaja de dejar caer conquistas ya alcanzadas. Y quiero las Humanidades como el vehículo natural para todo lo autóctono." Alfonso Reyes: "Discurso por Virgilio," en Obras Completas, vol. XI, p. 160-61.

2. See for example, Garibay 1962b: XI

3. See for example, Garibay 1953, I: 193.

4. Antoine Berman's work on translation criticism will be inmensely helpful in this respect, particularly the definition and analysis of ethnocentric and hypertextual translation (1985).

5. Reminding us of the teological dispute settled by Saint Paul: "the letter kills, the spirit vivifies," Corinthians, III-6, which has a profound bearing in the thinking about translation of religious texts.

6. An illustrated analysis of these characteristics is the subject of my paper: "La traducción como representación: Grecia en el Anáhuac," presented at the Primer Congreso Sudamericano de Historia, Santa Cruz, Bolivia, August 20-24, 2003.

7. Historia de la literatura náhuatl (2 vol.) Ed. Porrúa, Mexico, 1953-1954, and Poesía náhuatl (3 vol.) UNAM, Mexico, 1964-1968. 
8. 1956, 1959, 1966, 1974, 1979, 1983, 1993, 1997. Translations include 1961 (Russian), 1970 (German), and 1985 (French). English editions were published in 1963, 1970, 1971, 1975, 1978, 1980, 1982, 1985.

9. Although Benjamin Keen, already in 1971, expressed doubts about the same tenets that became the target of renewed criticism in the late 80's and early 90 's.

10. Already in 1982, anthropologist David Carrasco had pointed to the problem he defined as the difficulty of "establishing the text" (or the "original," in translation terms) in view of the "rupture in transmission of indigenous traditions caused not only by pre-Columbian upheavals but also by the conquest of Mexico and the colonial pressures of the sixteenth century." Carrasco observed that the authenticity of the texts thus produced should not be taken for granted and that it was "common for scholars working in this area to skim over the significant hermeneutical adjustments made by Spanish and Indian writers influenced by colonial politics, personal need, mendicant theology and language differences" (Carrasco 1982: 6).

11. Gruzinski 1988, p. 5-9.

12. He is known for his intolerance to criticism, but these articles were unusually bloody.

13. A quick search in the Internet English files attests to this fact.

14. For the first time English-speaking scholars have access to the Nahuatl text without having to resort to Spanish, therefore escaping the hermeneutic paradigm in which these texts have so far been studied.

15. "Extraño es [...] que una institución como el Consejo Nacional para la Cultura y las Artes [...] se dejaran sorprender y patrocinaran para su difusión en México la publicación de este libro. Es lamentable que autores de este tipo de trabajos [...] puedan sorprender no sólo a los editores del Consejo [...] sino malinformar y aun engañar en México a no pocos lectores... "(León-Portilla 1991: 307-308).

16. Alfredo López Austin, another Mexican anthropologist, was also drawn into the controversy by León-Portilla. In an article answering a criticism directed to his interpretation of the word ixtli, he pointedly notes that León-Portilla's interpretation has lead to a "so-called philosophical concept of prehispanic education that has been made known extensively by León-Portilla and has been accepted by the lay public." He also notes that León-Portilla's omnipresence in the editorial boards of scholarly publications has given him an undue vantage point in the controversy (López Austin 1991: 334-335).

17. Damrosch (1993: 148).

18. Damrosch proposes the theoretically attractive but pragmatically challenging idea that "most poems fall into an ambiguous gray area: they may be seen as coming from either period or, in a very real sense from both" (Damroch 1993: 153).

19. Although Garibay explains clearly that there are at least three meanings in the metaphor, and at least on one occasion he offers the different versions that would correspond to these meanings (see Garibay 1953, I: 73-74).

20. In his critical review, León-Portilla says: "Ya he recordado que el señor Gordon Wasson vio en flores y cantos evocaciones de los hongos alucinantes. Ahora Bierhorst nos dice que se trata de invocaciones para hacer que desciendan y vuelvan los espíritus de los grandes señores, los que gobernaron, los guerreros famosos. ¿habrá alguien que en el futuro sostenga que estos cantares fuerons inspirados a los nahuas por seres poseedores de gran sabiduría, venidos del espacio extraterrestre?" (León-Portilla 1986: 400).

21. Some exceptions are noted by Segala. Van Zanwijk (1997) too has observed some changes in León-Portilla's ways of translating over time.

22. Barthes, Roland "Le discours de l'histoire," Information sur les Sciences Sociales, v. 6, n. 4, 1967, p. 68-69.

23. Ometéotl (two-god) is considered the God of Duality (composed of a masculine principle: Ometecuhtli (two-lord) and a feminine principle: Omecihuatl (two-lady), who engendered all gods. 
24. Bierhorst's version, on the other hand, can also be branded a translation-introduction, now for another readership, and the model is also familiar to that readership: the rituals of recalling spirits documented for some North American tribes.

25. In Grenier, Yvon (selection and prologue), Octavio Paz. Sueño en libertad. Escritos políticos. Mexico: Seix y Barral, 2001.

\section{REFERENCES}

Barros, C. (1995): “La historia que viene." Proceedings of Conference "Historia a debate: pasado y futuro" (July 1993), Santiago de Compostela, pp. 97-117.

Barthes, R. (1982): “Le discours de l'histoire.” Poétique 49, pp. 13-21.

Berman, A. (1985): "La traduction de la lettre ou l'auberge du lointain," in Antoine Berman (ed.) Les tours de Babel, Mauvezin, Trans-Europ-Repress, pp. 31-150.

Bierhorst, J. (1985): Cantares Mexicanos, Songs of the Aztecs. Stanford: Stanford University Press.

Carrasco, D. (1982): Quetzalcoatl and the Irony of Empire, Myths and Prophecies in Aztec Tradition. Chicago and London, University of Chicago Press.

Damrosch, D. (1993): The Aesthetics of Conquest: Aztec Poetry Before and After Cortes. In Stephen Greenblath (ed.), New World Encounters. University of California Press.

Garibay K., Á. M. (1987): Historia de la literatura náhuatl. Mexico, Editorial Porrúa.

Garibay K., Á. M. (1962): Las siete tragedias de Esquilo. Mexico, Ed. Porrúa. Col. "Sepan cuantos..."

Garibay K., Á. M. (1962): Las siete tragedias de Sófocles. Mexico, Ed. Porrúa. Col. "Sepan cuántos...."

Garibay K., Á. M. (1999): Llave del náhuatl. Mexico, Editorial Porrúa.

Garibay K., Á. M. (1964): Poesía náhuatl. Mexico, UNAM-IIH.

Gruzinski, S. (1988): La colonisation de l'imaginaire. Sociétés indigènes et occidentalisation dans le Mexique espagnol, $X V I^{e}$-XVIII ${ }^{e}$ siècle. Paris, Gallimard.

Gutiérrez, N. (1999): Nationalist Myths and Ethnic Identities, Indigenous Intellectuals and the Mexican State. Lincoln, University of Nebraska Press.

Klor De Alva, J. (1998): Sahagún and the Birth of Modern Ethnography. In Jorge Klor de Alva et alii. (eds.), The Work of Bernardino de Sahagún, Albany, State University of New York.

León-Portilla, M. (1956): La filosofía náhuatl estudiada en sus fuentes, 7th ed. 1997. Mexico, Universidad Nacional Autónoma de México.

León-Portilla, M. (1986): “¿Una nueva interpretación de los Cantares Mexicanos? La obra de John Bierhorst.” Estudios de Cultura Náhuatl 18. Mexico, Instituto de Investigaciones Históricas, UNAM, pp. 385-400.

León-Portilla, M. (1991): “¿Una nueva aportación sobre literatura náhuatl: el libro de Amos Segala?” Estudios de Cultura Náhuatl 21. Mexico, Instituto de Investigaciones Históricas, UNAM, pp. 293-308.

León-Portilla, M. (1992): “Have We Really Translated the Mesoamerican Ancient Word?” In Brian Swann, On the Translation of Native American Literatures, Washington and London, Smithsonian Institute Press.

León-Portilla, M. (1992): "A modo de comentario." Caravelle. Cahiers du monde hispanique et luso-brésilien 2, pp. 221-223.

León-Portilla, M. (1994): Quince poetas del mundo náhuatl. Mexico, Editorial Diana.

León-Portilla, M. (1996): El destino de la palabra. De la oralidad y los glifos mesoamericanos a la escritura alfabética. Mexico, El Colegio Nacional-Fondo de Cultura Económica.

Locкнавт, J. (1991): "Care, Ingenuity and Irresponsibility: The Bierhorst Edition of the Cantares Mexicanos." In James Lockhart (ed.), Nahuas and Spaniards, Postconquest Central Mexican History and Philology, Los Angeles, UCLA Latin American Center Publications, University of California. 
PAYÀs, G. (2002): “El historiador y la traducción: una curiosa amistad," communication presented at the XII Encuentro de traducción literaria, Mexico City, October 2002.

PAYÀs, G. (2003): "La traducción como representación: Grecia en el Anáhuac," communication presented at the I Congreso Sudamericano de Historia, Sta Cruz, Bolivia, August 2003.

Segala, A. (1989): Literatura náhuatl. Fuentes, identidades, representaciones. (Mónica Mansour trad.) Mexico, Consejo Nacional para la Cultura y las Artes-Grijalbo.

Segala, A. (1992): "La literatura náhuatl, ¿un coto privado?" Caravelle, Cahiers du monde lusohispanophone 2, pp. 209-220. Université de Toulouse II-Le Mirail.

Van Zantwijk, R. (1997): "Las traducciones del náhuatl de Miguel León-Portilla," in In iihiyo, in itlahtol. Su aliento, su palabra. Homenaje a Miguel León-Portilla, Mexico, UNAM-El Colegio Nacional-INAH, pp. 125-135. 